\title{
The need for continued decolonisation and Africanisation of ordination in the Methodist Church of Southern Africa
}

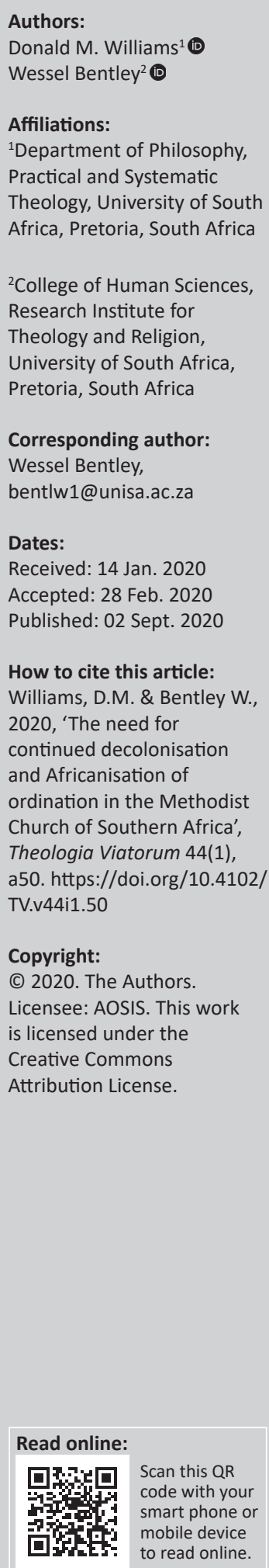

\begin{abstract}
Being the church in Africa requires a continuous self-assessment by Christian denominations, asking whether it is sufficiently contextualised both in its doctrines and practices. This selfcritique is essential so as to not perpetuate negative colonial influences in the way churches operate. The Methodist Church of Southern Africa (MCSA) has a rich history of challenging itself to become truly instrumental in working towards 'A Christ-healed Africa for the healing of the nations'. This article explores the history of the MCSA's engagement with its doctrine and practices of ordination, its journey of decolonisation and its presentation of an emerging Africanised theology of the presbytery.
\end{abstract}

Keywords: Africanisation; decolonisation; ordination; Methodist Church of Southern Africa; presbytery; Wesleyan theology.

\section{Introduction}

The Methodist Church of Southern Africa (MCSA) traces its origins to the mission work of the Wesleyan Methodist Church of the early 19th century in the Cape region of what is now known as the Republic of South Africa. Although there was already a Methodist presence in the form of British soldiers like Sergeant John Kendrick (a local preacher who arranged meetings for the Methodist soldiers in the Cape) (Millard-Jackson 2008:31), its work formally took shape with the arrival of missionaries like Rev. Barnabas Shaw in 1816, and later Rev. William Shaw (not related), who pioneered the establishment of Methodist mission stations throughout the Cape. Needless to say, the Christianity proclaimed by the Methodist missionaries carried a deeply colonial world view, and hence, its doctrines and practices reflected those of its 'mother' denomination. This article will reflect on the denomination's colonial heritage, its active engaging with decolonial processes and the journey of forming a unique Africanised doctrine, and practice of the ordination to Word and Sacraments.

\section{The colonial heritage of the doctrine of ordination in the Methodist Church of Southern Africa}

The Methodist work in Southern Africa was initiated by the Wesleyan Methodist Church in England through the Wesleyan Methodist Missionary Society in the early 1800s among the British settlers and the indigenous people of this region. The missionaries were ordained presbyters who were accountable to the Conference of the Wesleyan Methodist Church in England for their discipline, conduct, doctrine and their stationing to a circuit and 'were expected to transplant English Methodism in alien soil' (Cragg 2011:25).

The ecclesiology, doctrine of ordination, procedures from candidature to ordination, accountability of presbyters to the conference and the practices and liturgy relating to ordination replicated those of the Wesleyan Methodist Church in England. These were formally adopted into the Southern African Connexion with the holding of the first Conference of the Wesleyan Methodist Church of South Africa in 1883 and continued until 1927 when the South African Conference 'became an independent and autonomous body' (Methodist Church of South Africa 1946:312).

The essential elements of the Methodist understanding of the doctrine of ordination include that God chooses some within the priesthood of all believers to be set apart and ordained to the presbyteral ministry of Word and Sacraments, a call that needs to be tested, recognised and affirmed by the conference. Acceptance as a probationer minister is followed by a time of formation and training that culminates in their acceptance into Full Connexion and entering into a covenantal 
relationship with the conference. Being in Full Connexion determines the relationship between the presbyter and the conference with the ordinands holding themselves accountable to the authority, doctrine and discipline of the conference which annually appoints presbyters to their station or circuit on the understanding that Methodist presbyters participate in an itinerant system of stationing. Being in Full Connexion also provides accountability, support and collegiality with the other presbyters in the connexion (Methodist Church of Southern Africa 2016:37).

It is the conference that authorises the Presiding Bishop and other previously ordained presbyters to conduct the ordination of the presbyter by the laying on of hands, the prayer of invocation to the Holy Spirit and the presentation of a Bible and Certificate of Ordination. Ordination sets the presbyter apart to the full-time ministry of the Word and Sacraments, with ordination being 'the act by which Christians are authorised by the Church to act in its name and on its behalf in certain ways' (Methodist Church of Southern Africa 2016:20). Ordination confers authority on the presbyter to minister within the Church of Christ under the direction of and accountability to the annual conference. Significantly, these elements inherited from the Church of England and the Wesleyan Methodist Church in England continue to be the foundation on which is built the doctrine of ordination in the MCSA today.

Together with the colonial ecclesiology and doctrine of ordination arose practices that impacted the ministry of the Methodist denomination in Southern Africa. The prevailing narrative during the early years of this denomination was of the dominance of Western culture over African culture. The indigenous people were regarded as heathen together with many of their traditional values, religious beliefs and cultural practices being rejected. The colonial narrative was compounded by racism and sexism expressed in a reticence to ordain both black (initially) and women preachers.

The colonial narrative resulted in the creation of parallel structures based on ethnicity that was often perceived and experienced as discriminatory. These included racially separated ministerial training and formation, separated synod sessions and ordination services, differentiated stipends and the marginalisation of black and women presbyters who were denied the opportunity to serve in the positions of leadership. The more insidious and damaging consequences of colonialism were the negative and enslaving impact on the worth, thinking and being of black persons and black presbyters serving in the church. Colonialism 'made them a conquered people and empty shells that accepted everything coming their way' (Lephakga 2015:146).

In response to these measures and the demands for a decolonised and Africanised Methodist Church to be relevant in the Southern African context, a number of adaptations took place. These were a continuous process over an extended period of time to adapt from a colonial missionary context to an established denomination on the African continent. The inclusion of women as presbyters and the introduction of the annual Presbyters' Convocation (MCSA 2018a:93) that meets prior to the annual synods and reports to the synod are significant amendments to the doctrine of ordination. The practices associated with ordination have also been extensively modified in the past two centuries. These include the following:

- The change from a reluctance to ordain black persons to an acceptance of preachers of all cultural and racial origins.

- The change from holding racially separated Black and White Ministerial Sessions of Synod to Joint Ministerial Sessions.

- The change from racially determined stipend and benefits received by presbyters to equity-based stipends and benefits across the board

- The change from racially defined ordination services to one common ordination service per annum

- The change from only Methodist presbyters being involved in the ordination service to the acceptance of presbyters from other denominations to participate in the laying on of hands at ordination presbyters being the only ones to officiate at an ordination service to the inclusion of the Lay President in the liturgy of the service of ordination.

- The change from racially segregated training and formation to the combining of ministerial training and formation at a common institution.

The boundaries of ethnicity have also been crossed by acknowledging black presbyters with their appointments into leadership positions at circuit, district or synod and connexional level. Black presbyters have served as the Presidents of Conference or Presiding Bishops from 1987 to the present and will continue to do so with the Rev. Purity Malinga (the first woman to occupy this post) being elected in 2019 to serve in this capacity for the next 5 years. The crosscultural formation, training and stationing of probationer ministers and presbyters are now accepted practices of the denomination.

Another example of where adaptations have been made relates to the assessment of probationer ministers in their formation and readiness for ordination. While the annual synod will recommend their advancement in probation and their readiness for ordination by means of a democratic vote, the final decision is made by committees accountable to the Education, Ministry and Mission Unit. In these committees, a more congruent methodology of 'consensus decisionmaking' that is more congruent with the African context of consultation, deliberation and consensus-seeking is practised (Broodryk 2010:39).

Specific amendments relating to the ecclesiology and the incorporation of the ministry of the laity and their relationship 
with the presbyteral ministry have also been introduced. The Journey to the New Land Convocation in 1993 was a significant step in the transformation of the church, especially from the perspective of the laity. The convocation introduced more participatory, consultative and inclusive processes; reemphasised the doctrine of the priesthood of all believers 'to value and enhance the gifts and ministry of all God's peoplewomen and men, laity and clergy, young and old' (Methodist Church of Southern Africa 1993:374); and introduced the office of a Lay President of Conference 'to give recognition to the importance of the laity' (Methodist Church of Southern Africa 1995:310). The convocation also led to the transformation of the separate clergy and lay sessions of synod and conference to a combined session where the laity could participate in decision-making relating to not only the functioning of the church but also the training and ordination of its clergy.

Some changes to the ordination service have also been made to celebrate its African context. The liturgical changes include that hymns and Bible readings are multilingual, songs in the vernacular are supported by African rhythm and musical accompaniment, and the African sense of community is celebrated in sharing the peace with one another in song and dancing. Other additions are the inclusion of the liturgies relating to the recognition of common ministry and reaffirmation of baptism, declaring that:

Ministry is the work of God, done by the people of God. Through baptism all Christians are made part of the priesthood of all believers, the church, Christ's body, made visible in the world. (Methodist Church of Southern Africa 2019b:6)

In evaluating the colonial heritage of the doctrine and practices of ordination, and in spite of the adaptations that have taken place over the centuries, certain conclusions can be drawn. In reality, the essential elements to the doctrine of ordination remain closely aligned with the colonial theology adopted from the Wesleyan Methodist Church in England in 1882. These similarities extend to the polity and processes from a person's call to their ordination, their acceptance into Full Connexion, the authorisation by the conference for the presbyter to be ordained and the act of ordination by previously ordained presbyters that includes the laying on of hands and the prayer to the Holy Spirit. A comparison of the liturgy of the 2019 Ordination Service of the MCSA (Methodist Church of Southern Africa 2019b:1-16) with that of the Methodist Church in Great Britain ${ }^{1}$ highlights that the doctrines and practices recorded in the 2019 liturgy remain very British and colonial. In addition, the dominant ethos, narrative and culture of the MCSA remain European and Western.

The conclusions to be drawn are that not only was the MCSA very English in the past but also it remains very English in its

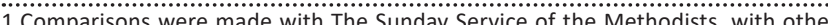
(Wether occasional services (Wesley 1788.285-296), the Book of OMces (Methodist Church 1936.134-154), the 1999 Methodist Worship Book (Methodist Church 1999:298-312) and the Ordination Service 2017 of the British Conference (Methodist Church 2017:1-22). doctrine and practices. While ordination is now, theoretically, free of ethnic and gender exclusivity, white domination and patriarchy and is inclusive of the complementary role and ministry of the laity, there is a blurring of the lines between doctrine and practices and between intention and practices. The MCSA has not adequately adapted either the doctrine or the practices of ordination from our colonial past. Significant aspects of African culture and spirituality are not sufficiently incorporated into or evident in our present theology and practices.

\section{The places of incongruity between the tradition of the Methodist Church of Southern Africa and its African context}

A closer examination of the Southern African context reveals that some incongruities are evident between the present tradition of the MCSA and practices in ministerial formation and ordination and the African context. These will now be examined.

\section{The culture of calling and dress}

The first example of incongruity is in the selection and discernment processes relating to candidates for the ordained ministry when expressing their call by God to the district synod. When considering what may be deemed to be acceptable criteria to be included in sharing one's call, some candidates fear that 'things like visions and dreams may not be accepted as valid in articulating their call' (V.G. Nyobole [Past General Secretary of the MCSA and presently serving as the President of the Seth Mokitimi Methodist Seminary] pers. comm., 02 October 2018). When interviewed on 16 October 2018, similar sentiments were expressed by I.M. Abrahams, past presiding Bishop of the MCSA and presently serving as the General Secretary of the World Methodist Council, noting that:

\footnotetext{
... [W] e have black candidates for the ministry talking about dreams and being called, but they stop short in saying this is the ancestors speaking to them. They dress it up in more respectable language. (I.M. Abrahams pers. comm., 16 October 2018)
}

Furthermore, the lack of an African cultural influence on the dress code of presbyters and preachers is evident in the prescribed wearing of suits or cassocks and stoles by presbyters, all of which are a heritage of the colonial era (Attwell 2004:1-4; Methodist Church of Southern Africa 2018b:5). During the ordination service, there is little of the dress code of African people and their cultures in evidence either on the stage or in the congregation. The fact that the ordinands are required to wear a black cassock is in keeping with the dress requirements while at Seth Mokitimi Methodist Seminary (SMMS) for formal occasions, at the community monthly communion service and when fulfilling their preaching appointments in the surrounding churches (L.G. Sifo [Dean of the Chapel and Head of Formation at the Seth Mokitimi Methodist Seminary] pers. 
comm., 19 October 2018). The attire of the bishops is also consistent with their dress code when performing their formal functions as the Bishop of a Synod, dressed in white cassocks and stoles.

\section{The stationing and remuneration of presbyters}

The significance of the role of inclusiveness in African culture is not sufficiently incorporated with Setiloane (1986) drawing our attention to the premise that 'a primary characteristic of African "being" is its inclusiveness" (Setiloane 1986:37).

The MCSA remains colonial in its stationing practices where the practice was to station presbyters to their various circuits according to the ethnicity of the presbyter and of the circuit to which they were appointed. While this practice is not as prevalent as it used to be, it remains the exception for a white presbyter, for instance, to be stationed in a predominantly black context when many black presbyters are stationed in a predominantly white context. In addition, the ability of a circuit to afford the appointment of a presbyter results in an inequitable distribution of ministry favouring richer urban circuits to the detriment of those members in rural and poorer areas. In an attempt to rectify this practice, the Conference of 2019 resolved that 'the MCSA is to station agency as per the need for such agency instead of the current approach which is largely informed by affordability' (Methodist Church of Southern Africa 2020).

A further consequence of black presbyters being appointed to the rural and poorer circuits is that many of those presbyters do not receive a regular monthly stipend or additional benefits as compared to their white colleagues in the urban and more affluent appointments. In practical terms (Mtshiselwa 2015):

... [I]t means that in terms of the stationing system of the MCSA, white ministers are immune to being placed in a context of poverty where they could possibly leave without a source of income. (p. 7)

Consequently, many black presbyters have suffered financially, both during their time of ministry in those poorer circuits and on their retirement with decreased pension benefits.

Questions are also being raised as to the suitability and congruence of the colonial practice of the itinerant stationing of presbyters within a connexional model, with Rev. Morgan stating:

There is nothing African about itinerancy. The idea of having to move and be a stranger every three or five years in a new community is very disruptive and you cause disruption and dissatisfaction in a community. (C. Morgan [General Secretary of the MCSA] pers. comm., 23 November 2018)

She speculates on the impact the church could have in a community where the obvious successor had to rise up from within the community, be trained, ordained and then lead the community as someone who was known to and trusted by them (C. Morgan [General Secretary of the MCSA] pers. comm., 23 November). While the colonial itinerant stationing processes of presbyters by the conference were applicable in the times of Rev. Wesley, for Southern Africans, it is a practice reminiscent of the migrant labour system of the past in South Africa and the one that is not conducive to the well-being of the clergy family. ${ }^{2}$

\section{Ceremonies and celebration of events}

The significance of ceremonies and the manner in which African culture celebrates events with the inclusion of ritual, symbolism, dance and song are not sufficiently incorporated into the present theology and practices of ordination. Edet (2010:305-315) notes that:

Ritual is a means by which humanity controls, constructs, orders, fashions, or creates a way to be fully human. Indeed, it gives meaning to the world, renews, and makes this right. It saves, heals, and makes whole again. Hence, ritual is necessary in our lives. (p. 306)

$\mathrm{Ng}^{\prime}$ weshemi (2002) endorses the importance of ritual and rites of passage associated with the life cycle of a person from one stage to another, as they also define the relationship of the community to an individual's changing place in the community' ( $\mathrm{Ng}^{\prime}$ weshemi 2002:19). The importance of ritual is that: 'For Africans, one is not human simply by birth. Rather, one becomes human through a progressive process of integration in society' (2002:19). Ritual and celebration are important elements in creating and celebrating holism, vitalism and communalism as they provide a coming together of people with opportunities for the community to bond and to support one another.

Forms of ritual are present in the ordination service such as the processional entry into the service, the dress code of those on the stage, movement and dancing while singing, the laying on of hands, the opportunity for family and friends of each ordinand to stand during the ordination of those known to them and the celebration of the sacrament of Holy Communion. However, there is an incongruity between the intention and experience of the ordination service that is not discernibly African in character as there is a paucity of Southern African ritual, symbolism and celebration evidenced in the service of ordination. In the words of Rev. V.G. Nyobole [Past General Secretary of the MCSA and presently serving as the President of the Seth Mokitimi Methodist Seminary] pers. comm., 02 October 2018): '[ $t]$ here is not much of an African vibe in it'. Significant questions are raised by Rev. Mntambo asking:

If I had to conduct our ordination service in London, would the people ask: What do they mean by that? Why is that in there? I don't think they will because it is a straightforward English [Western] service. (T.V. Mntambo [Bishop of the Limpopo Synod of the MCSA] pers. comm., 23 November 2018)

2.See Williams and Bentley (2016:23-25) for a fuller description of the implications of presbyters being in a covenant relationship with the MCSA and how that impacts their well-being. 


\section{Connectedness}

The Southern African concept of the connectedness of people with each other is encapsulated in the Methodist concept of Connexionalism. However, neither the depth of the African concept of connectedness emphasising a deeper and broader significance than a personalised experience for the individual nor the relationship of the living dead to the present community is incorporated into our present formulations and liturgy. This understanding is readily accepted in African culture with the Rev. W.M. Molo ([Methodist presbyter and Chairman of the Black Methodist Consultation of the MCSA], pers. comm., 25 October 2018) explaining:

At the core of African Spirituality is the idea of connectedness ... When I get ordained I am not starting something new. I am joining millions of people who came before me and who have been serving God ... Ordination is being set aside. Because we are being set aside, we need to connect with the departed. That's what we do with the laying on of hands so that people are set aside. We can create a liturgy which allows us to connect with those who have come before us, those who have been ordained.

The significance and meaning of connectedness in African culture, together with the significant role that women fulfil in the life of the community and home, continues not to be the experience of women presbyters. During the colonial dispensation, women presbyters plead for an end to discrimination and patriarchy and for justice, recognition and a rightful place in the leadership of the church. These pleas are being made by African feminist authors, both within and outside of the MCSA. ${ }^{3}$

The concept of connectedness in the relationship between the ministries of the clergy and the laity, as captured in the doctrine of the priesthood of all believers (Methodist Church of Southern Africa 2016:12), is not being experienced as the 'co-equal and mutually dependent role of lay and ordained ministers' (Forster 2007:2) but has led to clergy elitism. It must be borne in mind, however, that the colonial foundation of clergy elitism is compounded by traditional African cultural practices of African kingship and the sacralising of human authority. This practice is borne out by the statement of Magezi (2015) that:

African kingship conveys on the ruler sovereignty, power, authority and supremacy over people under one's jurisdiction ... Consciously or unconsciously, church leaders tend to embrace the African kingship approach to leadership and to a lesser extent biblical servant leadership. (pp. 1-9)

The conclusion to be drawn is that, in spite of the historical adaptations that have taken place to the doctrine and practices of ordination, it appears very difficult for the MCSA to rid itself of the prevalent colonial Western narrative and to incorporate an African epistemology. The fact that the MCSA is ministering in an African context is not clearly reflected in our theology and practices. We have remained colonial in our practices, and our institutional culture remains Eurocentric and paternalistic. The depth of meaning in African culture and African spirituality is not sufficiently incorporated into our present theology and practices, including an insufficient emphasis on the concepts of inclusiveness, connectedness, the relevance of the living dead (ancestors) and the richness of African celebrations of significant events.

There is a dissonance between the declared intention of the MCSA to be 'an authentic African Church' (Methodist Church of Southern Africa 1994:376) and for 'our theology and practices to be homebrewed - cooked in African pots' (Methodist Church of Southern Africa 2006:15) and the experience of presbyters and the formulations, practices, structures and the dominant narrative which remain very Western and colonial. While the vision of the MCSA is 'A Christ-healed Africa for the healing of nations' (Methodist Church of Southern Africa 2019a:2), this is not the reality experienced and expressed optimally within the Southern African Connexion.

However, it is important to note that, associated with the detrimental colonial influences, patriarchy and sexism also have a damaging impact on the doctrine and practices of the church and therefore need to be examined.

\section{What would happen if nothing changes?}

In the light of the analysis in 'Introduction' and 'The colonial heritage of the doctrine of ordination in the Methodist Church of Southern Africa' sections, the appeal for the doctrine and practices of ordination to not only be decolonised but also Africanised is justified and appropriate. The decolonisation of the MCSA and the stripping of the systemic issues arising from colonialism must extend to the Africanisation of the MCSA. This shift must include the adoption and inculcation of an African epistemology to inform the very being and practices of the church and permeate the ecclesiology and doctrine of ordination. Is such a process permissible in the MCSA?

A historical analysis of the processes in England as well as the Southern African Connexion records that the theology, polity and practices of ordination in the Methodist Church are not static and have evolved and adapted to meet the needs of people when circumstances change. However, those calling for the Africanisation of the MCSA believe that the church has not adapted sufficiently to the African context and missional needs and that the outdated and discredited colonial narrative continues to influence the ecclesiology and doctrine of ordination as it is presently constituted. But what could that mean for the MCSA?

Some of the implications and consequences should significant changes not be made to the present doctrine and practices will now be considered. The overarching consequence is that unless our doctrines and practices are 'homebrewed ... cooked in African pots' (Methodist Church 
of Southern Africa 2006:15), it is impossible for the MCSA to be 'an authentic African Church' (Methodist Church of Southern Africa 1994:376) and will result in the Methodist witness within the Church of Christ in Southern Africa being diminished and ineffective. In addition, the MCSA will not be able to fulfil its mission statement that 'God calls the Methodist people to proclaim the gospel of Jesus Christ for healing and transformation' (Methodist Church of Southern Africa 2019a:2) nor implement the vision statement of 'A Christ-healed Africa for the healing of nations' (2019a:2).

The MCSA will also be denying the declaration of the 1958 Conference, meeting in a time of political upheaval and discrimination in South Africa and applying Wesley's teaching on Christian perfection to the South African context, ${ }^{4}$ pronouncing the Methodist Church to be 'one and undivided' (Methodist Church of South Africa 1958:202). It was the 1958 declaration that added an impetus and credibility to the witness of the Methodist denomination during the years of the apartheid struggle and into the new political dispensation post-1994. That impetus could be lost and the MCSA could well be irrelevant in future engagements relating to race, the concepts of blackness and whiteness and the relationship of each to the other. Being black and being African is neither being anti-white, exclusionary of white persons and their culture nor being intimidated or placed under the subjection of a white narrative. As Mtshiselwa (2016) comments:

Worthy of note also is the point that the ethos of blackness does not reject whiteness per se, but white supremacy which places black people at the periphery. (p. 5)

While written from a Dutch Reformed Church perspective, but equally valid in the context of the MCSA, Van Wyngaard (2014:157-170) warns that unless white Christians 'enter into a deeper reflection on their own identity', they will not be able 'to develop a theology that can engage with critical issues of "race" in a postapartheid South Africa' (Van Wyngaard 2014:158).

An additional implication is that the MCSA will be the poorer for the loss of the thinking and influence of black theology, black theologians, black feminist theologians and the rich contribution of African culture and spirituality. Also lacking will be the loss of a black epistemology underpinning the life and ministry of the church, remembering that 'African Christianity is about a way of being Christian that takes dialogue and context seriously' (Maluleke 2010:377) and the constant challenge to the reform presented by the Black Methodist Consultation of the MCSA (BMC):

... [T] hat exists for the Transformation of the MCSA into a truly African Church (in character, doctrine, ethos, identity and practice) by challenging and equipping Black Methodists to contribute meaningfully, actively and intelligently in the MCSA given the context of Africans. (Black Methodist Consultation 2015:2)

4.For a detailed description of the relationship between the 1958 conference statement and Wesley's doctrine of Christian perfection, see Forster (2008:418-421).
Importantly, changes are required not only to deal with the consequences of the colonial narrative but also to deal with the negative impact of aspects drawn from African culture and traditions that could reinforce the toxic aspects of the 'old' attitudes and practices associated with colonialism. Mokhoathi (2017:1-14) cautions us not to fall into the trap of 'adiaphora' (Mokhoathi 2017:1-6) that accentuates the positive while rejecting the negative aspects of African culture. It is also salutary to remember that doggedly adhering to traditionalism can entrap one 'in intellectual infertility' (Mbetwa 2018:151).

Specific concerns raised by authors relating to an African narrative include the 'sacralisation of power ... the tendency to deify figures of power ... and to legitimate a status quo of authoritarian rule' (Muller 2015:3-4). Gititi (2014:66, 69) warns of runaway dictatorship and the sense of 'inherited entitlement' and calls for accountability and restraints of power. ${ }^{5}$ The role of tribalism and ethnicity has also been raised within and outside of the MCSA. Writing in the November 2016 edition of New Dimension, Kamogelo Monoametsi raises the matter of tribalism and ethnicity in South African society by asking, 'Is the MCSA a united kingdom or a divided one? Do we see ourselves as representatives of the Kingdom of God or our ethnic and tribal kingdoms?' (Monoametsi 2016:13). A similar concern was raised by the Conference of 2006 with 'race, gender, language and tribal identity' (Methodist Church of Southern Africa 2007:7) being cited as factors in the stationing of presbyters.

Authors also highlight a possible negative impact of communalism in African culture where the harmony of the group logically means that the individual's insights, needs and autonomy are of lesser importance; they are subsumed to the needs of the collective' (Kretzschmar 2008:86). The danger that communalism 'thinks for you, plans for you and decides for you under the façade of benevolent oversight' (Mbetwa 2018:55) is important in the context of an Africanised doctrine.

A timeous warning by Storey (2014) is that:

... wherever the church is too ready to uncritically validate the culture around it, whether in Europe, the Americas, Australasia or in Africa, theology is subsumed and culture prevails. Christ becomes diluted and theology is hijacked by not just the virtues but also the sins of the culture. (pp. 75-88)

A significant reason for further adaptations is to deal with the difficulty experienced by African people, including Methodist presbyters, of having to live in two worlds - traditional and 'Christian' - as explained by Setiloane (1986) when he states: 'What has been happening in Africa is that African Christians have been living at two levels: their traditional African world view level and the Western cultural level' (Setiloane 1986:31). The challenge of Grassow (2015) is:

5.See also Ndîgîrĩgĩ (2014:187-188) 
We still need to engage the split spiritual personality of our members who are Methodist by day, and African Initiated Church by night. This includes the way we use traditional cultural practices at home, but hide them from our Methodist community as if being African was not acceptable in the Methodist Church. (pp. 1-3)

\section{Some suggestions}

As further adaptations and changes are essential, some suggestions in order to further Africanise the doctrine and practices of ordination and to inculcate a dominant Southern African epistemology will now follow.

\section{Greater community participation in processes relating to ordination}

Greater community participation based on an African narrative in the processes relating to ordination would help in the transformation process. There needs to be an increased role of the local community, using an African epistemology and methodology, in the screening and selection of candidates for the ministry of Word and Sacraments. There must be a clearer understanding of the criteria and methodology, from an African perspective, for the screening, selection and acceptance of candidates who are presently very Western. In the words of Rev. Nyobole:

...[T] he MCSA needs to determine the kind of instruments we want to use to test that call. We need to determine what it is that we are looking for and whether that will be determined by our Western or African ideas,... remembering that in our Western way, things like visions and dreams are not seen as valid in articulating that call. (V.G. Nyobole [Past General Secretary of the MCSA and presently serving as the President of the Seth Mokitimi Methodist Seminary] pers. comm., 02 October 2018)

A further proposal is that the role and voice of the greater community also need to be heard in declaring ordinands 'worthy' of being ordained. In a similar manner that the community affirms the call of persons to become traditional healers, particularly as a sangoma, the synod needs to hear how the local community affirms the personal call of a candidate for the ministry and their worthiness to be ordained. 'The voice of the people needs to be heard and synod needs to assess how the community have affirmed that call' (T.V. Mntambo [Bishop of the Limpopo Synod of the MCSA] pers. comm., 23 November 2018).

\section{The formation of presbyters prior to and following their ordination}

For an effective ministry into the future, the formation of presbyters at the SMMS in Pietermaritzburg must be increasingly Africanised, and the seminarians must be formed in accordance with an African narrative to meet the needs of the Southern African context. Presently, presbyters formed at SMMS still have to engage mostly Western sources as a consequence of the paucity of published material from an African perspective. In the words of Rev. Nyobole:

We are still too Western. One of the problems is that we have few African writers who are writing about African religion.
We have the Mbiti's and Setiloane's but we don't have new African writers coming in and writing. (V.G. Nyobole [Past General Secretary of the MCSA and presently serving as the President of the Seth Mokitimi Methodist Seminary] pers. comm., 02 October 2018)

The MCSA needs to, as a matter of urgency and importance, encourage black theologians to publish material to be used in developing an African epistemology during the formation of our presbyters. In addition, SMMS is encouraged to investigate and propagate African philosophies, African ways of thinking theologically and African ways of teaching.

The challenge of Naidoo (2016) is that:

...the dominant Eurocentric universality claim must continue to be challenged and dismantled in order to make room for other theological traditions to become included as partners in an authentic and mutual dialogue. (pp. 1-8)

This perception is an important one for the MCSA in the training and formation at SMMS and in post-ordination training through the Continuation Ministerial Formation programme (Methodist Church of Southern Africa 2018a:94), remembering that the 'Western menu is not free of salmonella' (Mbetwa 2018:187).

\section{The understanding of entering into Full Connexion is to be expanded}

The concept of being received into Full Connexion with the conference and other presbyters in the order of presbyters would be enriched by the understanding of African culture that:

Community has to do with our relationship to other human beings. It is in community that our $u M u n t h u$ is actualized as an inseparable and yet individuated Munthu. Therefore, human identity has a communal dimension. (Musopole 1998:28)

The concept of relationships within a community is supported by Ketshabile (2012) when he states:

Western Christian theology lays much more emphasis on individual conversion and accountability before God and the theology of a new people of God (or the church). In African Traditional religion, particularly Batswana religion, the emphasis is on community and not the individual. The implication of this is that the individual cannot exist outside the community and in turn community does not refer to the living only, irrespective of whether they are Christian or not. It refers to both those in the present life and those who have departed. (Ketshabile 2012:187)

The implications for the doctrine of being accepted into Full Connexion are twofold. The first is that adopting an African understanding of being received into Full Connexion could be expanded by a portion of liturgy:

... [I]ndicating that the ordination of the presbyter links them with those who have gone before who, having passed away, are present and celebrating with you much in the same way as invoking the Hebrew notion of a cloud of witnesses that is very African. (W.M. Molo [Methodist presbyter and Chairman of the Black Methodist Consultation of the MCSA], pers. comm., 25 October 2018) 
The suggestion is that a presbyter of long standing in the denomination is called upon to recall the heritage of ordination, even recalling the names of some of the 'Methodist Church Fathers and Mothers', to both inspire and challenge the ordinands to remember their heritage in Christ's service, in much the same way as an imbongi in African culture.

The second is a challenge of Forster (2019:1-20) that presbyters are required to accept the implications of their responsibility of being in connexion with one another, bound together in a shared humanity. His premise is that our theological conviction in a shared humanity presents us with an ethical responsibility: 'because we share one another's humanity, we are not only to recognize it, but also to work towards re-humanizing others, and in turn also re-humanizing ourselves' (Forster 2019:14-15).

\section{Africanising the ordination service}

With the ordination service continuing to be very Western, there are numerous ways to enhance the service into an African experience while remaining true to Methodist doctrine. Some of the possible adaptations include the call for 'a multilingual liturgy that is celebratory of the various languages of South Africa' (N.P. Malinga [Director of the Education for Ministry and Mission Unit of the MCSA] pers. comm., 24 October 2018) but one that is contextualised 'using the correct metaphors and not just translated from English' (W.M. Molo [Methodist presbyter and Chairman of the Black Methodist Consultation of the MCSA], pers. comm., 25 October 2018). N.P. Malinga ([Director of the Education for Ministry and Mission Unit of the MCSA] pers. comm., 24 October 2018) also suggests that the liturgy of the ordination service is non-participatory by nature with the Presiding Bishop, General Secretary and Director of Education for Ministry and Mission Unit (EMMU) being the dominant persons, making 'everybody else a spectator. It is not celebratory'.

In addition, more opportunities for the community to celebrate in song in the traditional African manner need to be incorporated, as described by Ketshabile (2012):

Their rhythmic melody propels a systematic stamping of the feet, the beating of the drum or generally a small cushion that looks like a small pillow called biti - 'the beat.' It plays the role of the African drum and facilitates the harmonious stamping of the feet and movement of the singers. (p. 247)

Such opportunities for celebration in song are provided during the ordination service. However, these opportunities need to be increased in order to change the ambience of the service to one that is less Western and more African, 'while singing, some people cry, pray, and dance, following the rhythms and lyrics of the various songs' (Butticci 2014:121).

The role and meaning of ritual and symbolism are to be increased. Ritual plays a central role in African society and is incorporated, for example, in celebrating the rites of passage for women at puberty, childbirth, marriage and widowhood and for men during their rites of passage to manhood.
Ritual also plays a significant role in African Independent Religions and African spirituality. The statement that 'Rituals are the sacramental self-realization of the individual or the church and are thus indispensable' (Edet 2010:313) supports this premise.

The concern, from the perspective of African culture and spirituality, is that the present acts of ritual incorporated into the ordination service do not sufficiently express 'symbolic meanings in addition to the physical drama and impact' (Mbiti 1969:121). Neither do they reflect the changed relationship of the presbyter with the community nor the acceptance by the community of that newly ordained presbyter. The incorporation of an additional rite from Southern African culture would enhance the Africanisation of ordination in keeping with the practices of Southern African culture of welcoming men and women home following their rites of initiation and on marriage (Mbiti 1969:121-122; Van der Wiel 2012:27-29).

Similarly, the significance of symbols and the use of symbols need to be enhanced. Each symbol incorporated into the service, for example, the bread and the wine in the sacrament of the Lord's Supper, needs to be presented to the congregation and their significance explained in a similar manner to which a mother presents her child to the family and community (Edet 2010:310-311), remembering that 'to show something ceremonially, whether a sign, an object, or a person, is to declare a sacred presence, to acclaim the miracle of a hierophany' (Edet 2010:311).

The introduction of symbols associated with traditional healing in African culture should also be incorporated in the light of the Mission Statement of the MCSA that 'God calls the Methodist people to proclaim the gospel of Jesus Christ for healing and transformation' (Methodist Church of Southern Africa 2019a:2). Rev. I.M. Abrahams (pers. comm., 16 October 2018) suggests the burning of imphepho, white sage, in much the same way as incense is used in the Anglican and Catholic traditions' (Abrahams 2018).

The final proposal is that, in terms of Methodist tradition, the elements of bread and wine are represented at the sacrament of Holy Communion by wafers on a platter and non-alcoholic grape juice in small communion glasses. In order to Africanise this practice, a suggestion is that, instead of wafers, the 'bread be cooked and distributed in a black pot, a symbol known to African people with the knowledge that these are the things of God' (L.G. Sifo [Dean of the Chapel and Head of Formation at the Seth Mokitimi Methodist Seminary] pers. comm., 19 October 2018).

\section{The dress code of presbyters to be more African}

The style and nature of the dress code of all presbyters during the service of ordination certainly requires attention in order to become more appropriate and relevant to the African context. The colonial dress code of the bishops and presbyters gives the impression that the service is taking 
place in Europe and not in Africa, with everyone similarly attired in cassocks, clerical collars and with the bishops wearing stoles. A very large proportion of the congregation also dresses in their uniforms of either their organisations or as clergy persons. There is little of the dress code of African people and their cultures in evidence either on the stage or in the congregation.

It is wise to remember that the style of dressing is also a statement relating to status and power. Grassow (2015) reminds us of this dilemma when he states:

The MCSA is captive in many parts to a western, materialist theology that is driven by wealth and glamour... and we want to see our leaders dressed in the garments of the powerful. (p. 1)

In doing so, we would do well to heed the words of Rev. Wesley:

I have advised you not to be comfortable to the world herein; to lay aside all needless ornaments; to avoid all needless expense; to be patterns of plainness to all that are around you.... Are you all exemplary plain in your apparel? (Outler 1986:382)

An Africanised doctrine of ordination must not allow an elaborate dress code by presbyters to give the impression of power and superior status.

\section{Introducing a 'Coming Home Celebration' following the ordination service}

A suggestion to be considered in an Africanised model was made by the General Secretary of the MCSA, Rev. C. Morgan (pers. comm., 23 November 2018), proposing that a 'Coming Home Celebration' be held that would allow for the ordination of the presbyter to be recognised and celebrated by either the circuit from which the ordinand proceeded to the conference or the 'home' community who helped raise and form the person spiritually up to the time of their candidature for the ministry. The provision of such a service may assist in reducing the numbers of people attending the ordination service, often at great expense; provide an opportunity for celebration for those not able to attend the conference; as well as provide a time of celebration appropriate to African culture.

\section{Reviewing doctrinal aspects relating to ordination}

There are two further adaptations to be considered. The first relates to the re-introduction of the participation by the Lay President in the laying on of hands at the ordination of presbyters in keeping with the doctrine of the priesthood of all believers, the inclusive nature of Southern African society and a commitment that the ministry of a presbyter is not superior to that of the laity. In the early 2000s, circa 2001-2003, the Lay President participated in the laying on of hands in keeping with the decision of the Conference of 2001 that: 'Because ordination is an act of the whole Church it is important that the ordaining presbyters (elders) include both lay and ordained persons' (MCSA 2002:13). The practice was, however, discontinued soon thereafter as 'there was a lot of resistance from the clergy and it was silently done away with because the Bishops did not find a plausible theological rationale' (Nyobole 2018a).

The second is that while the MCSA does not discriminate as to who can be ordained or the grounds of their gender or sexual orientation, the conference limits the authority granted to presbyters to fulfil their pastoral responsibilities to persons in a same-sex relationship. The MCSA prohibits a clergy person from conducting Civil Unions of members from the Lesbian, gay, bisexual, transgender, intersex and queer (LGBTIQ) community and does not permit its presbyters to enter into a Civil Union.

Amendments to the doctrine in both instances would significantly adapt the doctrine to our Southern African context. Both these adaptations need to be discussed in greater detail and will not be addressed comprehensively in this article, but will be addressed in the continuation of this research project.

\section{Conclusion}

Stemming from a British colonial history, the MCSA, for obvious reasons, finds itself having inherited understandings and practices that are largely Western in nature. The process of decolonisation is part of the church individuating, finding its own identity. This individuating needs to be accompanied by Africanisation of its understanding and practices so that the MCSA can truly and authentically be an African church in Africa, for Africa. This process is ongoing and requires the MCSA to be conscious of its need to be true to its calling to be a Christian church in the African context. This consciousness brings along an intentionality to constructively discern God's will and minister in a language that its context understands.

\section{Acknowledgements}

This article stems from a doctoral study conducted by Rev. Donald M. Williams at the University of South Africa.

\section{Competing interests}

The authors declare that no competing interest exists..

\section{Authors' contributions}

Both the authors contributed equally to this work.

\section{Ethical consideration}

This article followed all ethical standards for carrying out research without direct contact with human or animal subjects.

\section{Funding information}

This research received no specific grant from any funding agency in the public, commercial or not-for-profit sector. 


\section{Data availability statement}

Data sharing is not applicable to this article as no new data were created or analysed in this study.

\section{Disclaimer}

The views and opinions expressed in this article are those of the authors and do not necessarily reflect the official policy or position of any affiliated agency of the authors.

\section{References}

Attwell, T.B., 2004, Guidelines for the use of clerical vestments and formal Methodist ecclesiastical attire, pp. 1-4, viewed 06 December 2018, from https://www.smms. ac.za/wp-content/uploads/2019/08/GUIDELINES-FOR-THE-USE-OF-CLERICALVESTMENTS.pdf.

Black Methodist Consultation, 2015, Product/service information brochure, pp. 1-6, viewed 02 March 2017, from http://methodistbmc.yolasite.com/resources/ BMC2015 resources/BMC $\% 202015 \% 20$ Information $\% 20$ Brochure $\% 20-\% 20$ BMC2015 resources/BMC\%202015\%20Infor
PRODUCT\%20-\%20SERVICE\%20-\%20FINAL.pdf.

Broodryk, J., 2010, Africa is best, uBuntu School of Philosophy, Pretoria.

Butticci, A., 2014, 'Balancing Christianity, culture, and race: African Pentecostals in Italy', in R.D. Smith, W. Ackah \& A.G. Reddie (eds.), Churches, blackness, and contested multiculturalism: Europe, Africa, and North America, pp. 115-132, Palgrave Macmillan, New York, NY.

Cragg, D., 2011, A spark of grace: The Wesleyan Methodist Mission in South Africa 1816-1883, Methodist Publishing House, Cape Town.

Edet, R.N., 2010, 'Christianity and African women's rituals', in P. Kwok (ed.), Women and Christianity: Critical concepts in religious studies, vol. 2, pp. 305-315, Routledge, London.

Forster, D., 2008, 'Prophetic witness and social action as holiness in the Methodist Church of Southern Africa's Mission', Studia Historiae Ecclesiasticae 34(1), 411-434.

Forster, D., 2019, 'African Christian humanism and Christian perfection in the Methodist Church of Southern Africa', Journal of Black Theology 17(1), 1-20.

Forster, D.A., 2007, Ordained deacons and the sacraments in The Methodist Church of Southern Africa, pp. 1-15, viewed 02 October 2016, from https://www.smms. ac.za/wp-content/uploads/2019/08/ORDAINED-DEACONS-AND-THESACRAMENTS-IN-THE-METHODIST-CHURCH-OF-SOUTHERN-AFRICA.pdf.

Gĩtĩtĩ, G., 2014, 'Toxic Fathers: Henri The Laughing Cry as Emblematic African Dictator Novel', in E. Ndĩgĩĩgĩ (ed.), Unmasking the African Dictator, pp. 65-83, The University of Tennessee Press, Knoxville, TN

Grassow, P.S., 2015, The Black Methodist Consultation - From a white perspective, pp. 1-3, viewed 05 June 2017, from http://rockinthegrass.blogspot.co.za/.

Kretzschmar, L., 2008, 'Christian spirituality in dialogue with secular and African spiritualities with reference to moral formation and agency', Theologia Viatorum 32(1), 63-96.

Ketshabile, K., 2012, 'Methodist burial rites: An inquiry into the inculturation of Christianity among Barolong of Mahikeng, South Africa', DTh thesis, Boston University, Boston.

Lebaka-Ketshabile, L., 2016, 'Women in ministry', paper presented at the Annual conference of the Methodist Church of Southern Africa, September 2016, Tshwane, pp. 1-7.

Lephakga, T., 2015, 'The history of the conquering of the being of Africans through land dispossession, epistemicide and proselytisation', Studia Historia Ecclesiasticae 41(2), 145-163. https://doi.org/10.17159/2412-4265/2015/300

Magezi, V., 2015, 'God-image of Servant King as powerful but vulnerable and serving: Towards transforming African Church leadership at an intersection of African kingship and Biblical kingship to servant leadership', HTS Teologiese Studies/ kingship and Biblical kingship to servant leadership', HTS Teologiese
Theological Studies 71(2), 1-9. https://doi.org/10.4102/hts.v71i2.2907

Maluleke, T.S., 2010, 'Of Africanised bees and Africanised churches: Ten theses on African Christianity', Missionalia 38(3), 369-379.

Masenya, M. (ngwan'a Mphahlele), 2012, 'Without a voice, with violated body: Rereading judges 19 to challenge gender violence in sacred texts', Missionalia 40(3), 205-216.

Mbetwa, C., 2018, Why Africa is poor, Choolwe Mbetwa, Chingola.

Mbiti, J.S., 1969, African religions and philosophy, Heinemann, London.

Methodist Church, 1936, Book of offices, Methodist Publishing House, London.

Methodist Church, 1999, Methodist worship book, Methodist Publishing House, Peterborough.

Methodist Church, 2017, Ordination service, Shirley Methodist Church, 2017 pp. 1-24, Methodist Publishing House, London.

Methodist Church of South Africa, 1946, Laws and discipline of the Methodist Church of South Africa, 3rd edn., Methodist Church of South Africa: Book Room and Publishing Department, Cape Town.

Methodist Church of South Africa, 1958, Minutes 1958, Methodist Publishing House, Cape Town.
Methodist Church of Southern Africa, 1993, Minutes 1993, Methodist Publishing House, Cape Town.

Methodist Church of Southern Africa, 1994, Minutes 1994, Methodist Publishing House, Cape Town.

Methodist Church of Southern Africa, 1995, Minutes 1995, Methodist Publishing House, Cape Town.

Methodist Church of Southern Africa, 2002, Yearbook 2002, Methodist Publishing House, Cape Town.

Methodist Church of Southern Africa, 2006, Yearbook 2006, Methodist Publishing House, Cape Town.

Methodist Church of Southern Africa, 2007, Yearbook 2007, Methodist Publishing House, Cape Town.

Methodist Church of Southern Africa, 2016, The Methodist book of order: The laws and discipline of the Methodist Church of Southern Africa, 12th edn. (revised), Methodist Publishing House, Cape Town.

Methodist Church of Southern Africa, 2018a, Yearbook 2018, Methodist Publishing House, Cape Town.

Methodist Church of Southern Africa, 2018b, Constitutions of the organisations, 2nd edn., Methodist Publishing House, Cape Town.

Methodist Church of Southern Africa, 2019a, Yearbook 2019, Methodist Publishing House, Cape Town.

Methodist Church of Southern Africa, 2019b, Ordination service, pp. 1-16, Methodist Church of Southern Africa, Cape Town.

Methodist Church of Southern Africa, 2020, Yearbook 2020, Methodist Publishing House, Cape Town.

Millard-Jackson, J., 2008, 'Who called the tune?' in W. Bentley \& D.A. Forster (eds.) Methodism in Southern Africa: A celebration of Wesleyan mission, pp. 31-39, AcadSA Publishing, Kempton Park.

Mkhwanazi, F.S., 2014, 'Women ministers in mission with reference to the Methodist Church of Southern Africa', PhD thesis, University of Pretoria, Pretoria.

Mokhoathi, J., 2017, 'From contextual theology to African Christianity: The consideration of adiaphora from a South African perspective', MDPI Religion 8(12), 1-14.

Monoametsi, K., 2016, 'The elephant in the room', New Dimension 46(10), 13.

Mtshiselwa, N., 2015, 'The emergence of the Black Methodist consultation and its possible Prophetic Voice in post-apartheid South Africa', HTS Teologiese Studies/ Theological Studies 71(3), 1-9.

Mtshiselwa, N., 2016, 'Two hundred years of Methodism! A Black Theological inquiry into the Heritage of Methodism in Southern Africa 1816-2016', Studia Historiae Ecclesiasticae 42(3), 1-19. https://doi.org/10.17159/2412-4265/2016/1248

Mudimeli, L.M., 2011, 'The impact of religious and cultural discourses on the leadership development of women in the ministry: A Vhusadzi (womanhood) perspective', DTh thesis, University of South Africa, Pretoria.

Muller, R., 2015, 'Incarnation theology versus the Sacralisation of authority', HTS Teologiese Studies/Theological Studies 71(3), 1-9. https://doi.org/10.4102/hts. v71i3.2707

Musopole, A.C., 1998, 'Needed: A theology cooked in an African Pot', in K. Fiedler, P. Gundani \& H. Mijoga (eds.), Theology cooked in an African Pot, pp. 7-47, Kachere, Lilongwe.

Naidoo, M., 2016, 'Overcoming alienation in Africanising theological education', HTS Teologiese Studies/Theological Studies 72(1), 1-8. https://doi.org/10.4102/hts. v72i1.3062

Ndĩgĩrĩg̃, G., 2014, 'Performing resistance in Ngũgĩ's Wizard of the Crow', in E. Ndĩgĩrĩg (ed.), Unmasking the African Dictator, pp. 183-206, The University of Tennessee Press, Knoxville, TN.

Ng'weshemi, A.M., 2002, Rediscovering the human: The quest for a ChristoTheological Anthropology in Africa, Peter Lang, New York, NY.

Nyobole, V., 2018, email, 16 April, Nyobolevido@gmail.com.

Outler, A.C. (ed.), 1986, The works of John Wesley, Volume 3, Sermons III, pp. 71-114 Abingdon Press, Nashville, TN.

Setiloane, G.B., 1986, African Theology: An introduction, Skotaville Publishers, Johannesburg.

Storey, P., 2014, 'The quest for identity in the Methodist Church of Southern Africa', in E.M. Conradie \& J. Klaasen (eds.), The quest for identity in so-called mainline churches in South Africa, pp. 75-88, Ecumenical Foundation of Southern Africa, Stellenbosch.

Van der Wiel, R., 2012, The African cultures of South Africa: The Xhosa people, Awareness Publishing Group, Johannesburg.

Van Wyngaard, C., 2014, "The language of "diversity" in reconstructing Whiteness in the Dutch Reformed Church', in R. Smith, W. Ackah \& A.G. Reddie (eds.), Churches, blackness, and contested multiculturalism: Europe, Africa, and North America, pp. 157-170, Palgrave Macmillan, New York, NY.

Wesley, J., 1788, The sunday service of the methodists, with other occasional services, London, viewed 17 June 2017, from https://archive.org/stream/soccaofm00wesl\#page/ 26/mode/2up.

Whitby, F., 2016, 'Confronting racism and sexism in the church', in paper presented at the Mission Congress of the Methodist Church of Southern Africa, Seth Mokitimi Methodist Seminary, November 24-27, pp. 1-10.

Williams, D. \& Bentley, W., 2016, 'The covenantal relationship between the Methodist Church of Southern Africa and her Ministers: An ethical appraisal', Studia Historiae Ecclesiasticae 42(2), 14-29. https://doi.org/10.17159/2412-4265/2016/1219 